\title{
Chimaereicella boritolerans sp. nov., a boron- tolerant and alkaliphilic bacterium of the family Flavobacteriaceae isolated from soil
}

\author{
Correspondence \\ Toru Fujiwara \\ atorufu@mail.ecc.u-tokyo.ac.jp \\ Iftikhar Ahmed \\ iftikharnarc@hotmail.com
}

\author{
Iftikhar Ahmed, ${ }^{1,2}$ Akira Yokota ${ }^{3}$ and Toru Fujiwara ${ }^{1,4}$ \\ ${ }^{1}$ Biotechnology Research Center, University of Tokyo, Yayoi 1-1-1, Bunkyo-Ku, Tokyo \\ 113-8657, Japan \\ ${ }^{2}$ National Agricultural Research Centre, Park Road, Islamabad-45500, Pakistan \\ ${ }^{3}$ Institute of Molecular and Cellular Biosciences, University of Tokyo, Yayoi 1-1-1, Bunkyo-Ku, \\ Tokyo 113-8657, Japan \\ ${ }^{4}$ SORST, JST, Chiyoda-Ku, Tokyo, Japan
}

Several classes of micro-organisms have been recognized as extremophiles, which inhabit environments with extreme levels of salinity, $\mathrm{pH}$, pressure, heat, cold and even radiation. These extremophiles provide a source of discoveries in the basic and applied sciences. We present the boron tolerance of bacteria as a new frontier in extremophiles. The toxic effects of high concentrations of boric acid on living cells are well established (Nable et al., 1997). The biological functions that require boron in microbes and plants are not clear, despite the fact that boron is required by some organisms as an essential nutrient (Warington, 1923; Rowe \& Eckhert, 1999). Although boron salts have often been used in microbial growth media (Stanier et al., 1966), boron essentiality and tolerance to boron toxicity in bacteria has only been reported recently (Ahmed et al., 2007a, b).

The GenBank/EMBL/DDBJ accession number for the 16S rRNA gene sequence of the strain $\mathrm{T}^{-} 22^{\top}$ is $\mathrm{AB} 197852$.

Maximum-likelihood and maximum-parsimony trees based on $16 \mathrm{~S}$ rRNA gene sequence data are available as supplementary material in IJSEM Online.
Recently, the genus Chimaereicella was described in the family Flavobacteriaceae; only one species, Chimaereicella alkaliphila, which was isolated from a non-saline but highly alkaline aquatic environment, has currently been characterized (Tiago et al., 2006). Most members of the family Flavobacteriaceae are Gram-negative and originate from marine and marine-derived surface waters (Bowman \& Nichols, 2005). These organisms play a major role in the remineralization of organic matter (Kirchman, 2002).

In the course of exploring the bacterial diversity of boron tolerance, we isolated a novel strain of Gram-negative, alkaliphilic and highly boron-tolerant bacterium from soil sampled from the Hisarcik area in the Kutahya Province of Turkey. This area is naturally high in boron minerals (Çöl \& Çöl, 2003). Based upon the data obtained, we propose that the strain represents a novel species of the genus Chimaereicella.

Strain $\mathrm{T}-22^{\mathrm{T}}$ was isolated from soil according to previously described isolation and enrichment procedures (Ahmed et al., 2007a). After isolation, the strain was cultured 
routinely on R3V-A medium (see composition in Tiago et al., 2006) or marine agar 2216 medium (MA; Difco) $(\mathrm{pH} 8.0)$ at $30^{\circ} \mathrm{C}$ or stored as glycerol stocks $(35 \%, \mathrm{w} / \mathrm{v})$ at $-80^{\circ} \mathrm{C}$.

The motility and morphology of cells were observed using phase-contrast microscopy and scanning electron microscopy (SEM). Gram staining was performed according to Hucker's modified method (Cowan \& Steel, 1974). Colonial morphology was observed on isolated colonies grown on R3V-A or MA medium ( $\mathrm{pH}$ 8.0). For SEM observation, cells grown on agar plates for 5, 10 and 22 days were removed, washed with PBS and fixed with $\mathrm{OsO}_{4}$. After dehydration by sequential washing with ethanol (50-100\%) that was exchanged to $100 \%$ isoamyl acetate, the sample was treated with platinum before observation using SEM (JEOL model JSM-6700F). Young cells of strain T-22 ${ }^{\mathrm{T}}$ in mid-exponential phase were non-motile and rod-shaped, with a length of $1.2-3.4 \mu \mathrm{m}$ and width of $0.3-0.4 \mu \mathrm{m}$; however, long filamentous cells (up to $15 \mu \mathrm{m}$ ) were also observed (Fig. 1a). Older cells (22 days) produced coccoid cyst-like structures or fruiting-body-like structures (Fig. 1b, c), with a diameter of $0.76-0.90 \mu \mathrm{m}$. The colonies produced red pigmentation that was diffusible into the medium.

The $\mathrm{pH}$ range for growth of the strain was determined on RV3-A or MA media with $\mathrm{pH}$ ranging from 4.0 to 10.0 (in $\mathrm{pH}$ increments of 0.5 ), adjusted as described by Tiago et al. (2006) at $30^{\circ} \mathrm{C}$. The temperature range for growth of the strain was determined on agar medium with $\mathrm{pH} 8.0$ by incubation at various temperatures $(4,10,16,20,25,28,30,32,37,45$ and $\left.50{ }^{\circ} \mathrm{C}\right)$. Growth of strain $\mathrm{T}-22^{\mathrm{T}}$ was also examined at levels of $\mathrm{NaCl}$ ranging from 0 to $7 \%(\mathrm{w} / \mathrm{v}$, in $1 \%$ increments) on $\mathrm{RV} 3$ A medium at $\mathrm{pH} 8.0$ and $30^{\circ} \mathrm{C}$. Strain $\mathrm{T}-22^{\mathrm{T}}$ grew on agar with a $\mathrm{pH}$ range of 6.5-10.0; however, it exhibited optimum growth at an alkaline $\mathrm{pH}$ of 8.0-9.0, so it was characterized as alkaliphilic according to the definition of Jones et al. (1994). The intensity of red pigmentation decreased at $\mathrm{pH} 10.0$, whereas it was maximal at neutral $\mathrm{pH}$. The optimum temperature for growth was $28-30{ }^{\circ} \mathrm{C}$. Slight growth was observed at 16 or $37^{\circ} \mathrm{C}$ after several days; no growth was observed at 10 or $40^{\circ} \mathrm{C}$. Strain T- $22^{\mathrm{T}}$ tolerated up to $3 \% \mathrm{NaCl}$.

Catalase and oxidase tests were performed following previously described procedures (Ahmed et al., 2007a). The strain was positive for catalase and cytochrome oxidase tests. Carbon source use was investigated using API $50 \mathrm{CH}$ strips (bioMérieux), using $0.1 \mathrm{M}$ Tris/ $\mathrm{HCl}$ buffer $(\mathrm{pH} 8.0)$ supplemented with $0.3 \%(\mathrm{w} / \mathrm{v})$ agar, $0.7 \%$ yeast nitrogen base and $0.05 \%$ yeast extract as a minimal medium. Acid production on various substrates was determined using $50 \mathrm{CHB} / \mathrm{E}$ medium with or without adding $0.02 \mathrm{M}$ Tris/HCl buffer ( $\mathrm{pH}$ 8.0) following the manufacturer's instructions and as described by Tiago et al. (2006). Results were recorded after 24 and $48 \mathrm{~h}$ and 5 days of incubation at $30^{\circ} \mathrm{C}$. Other physiological tests were performed using the API 20NE system (bioMérieux) using the minimal medium described by Tiago et al. (2006). Resistance to antibiotics and enzyme activities were evaluated using ATB-VET and
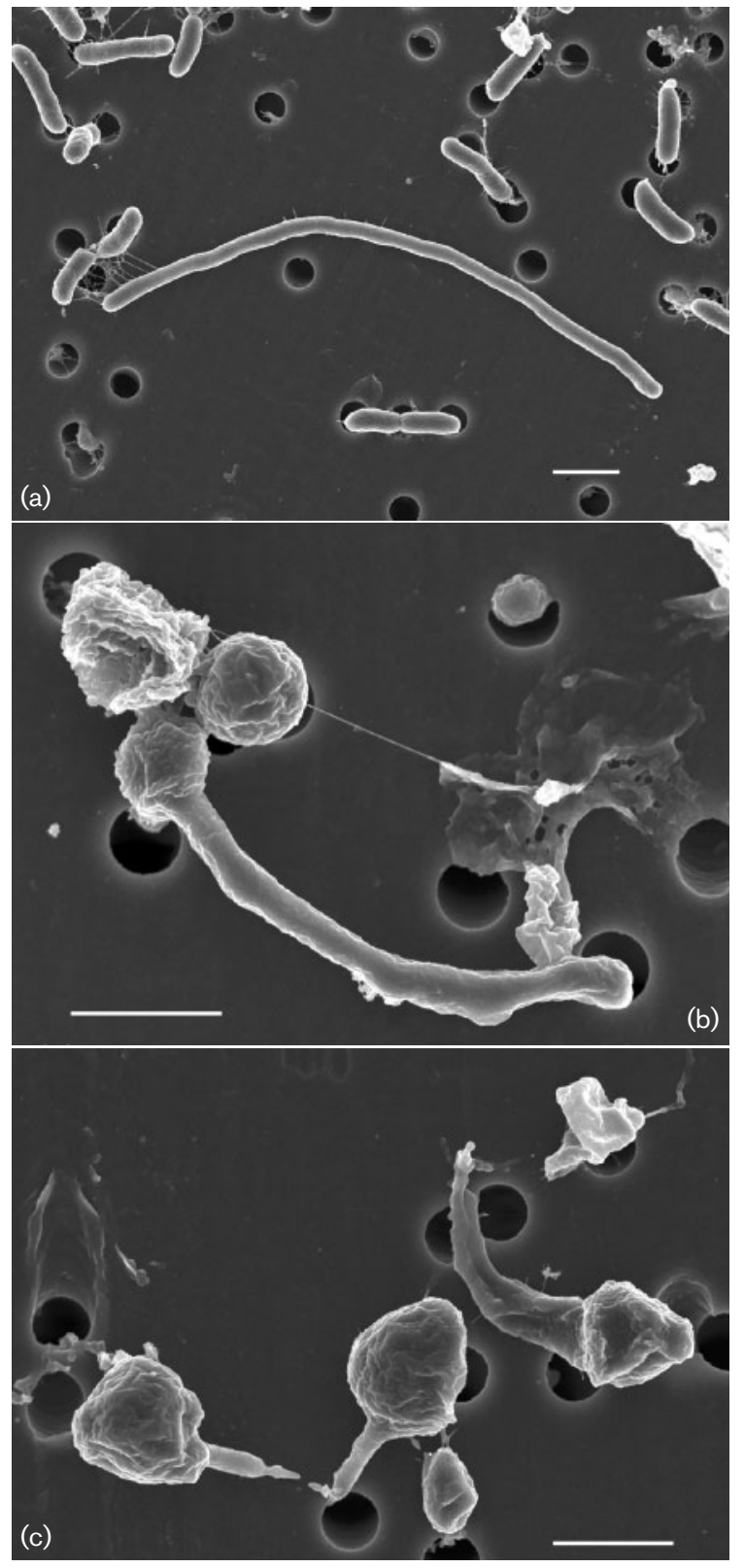

Fig. 1. Scanning electron micrographs showing vegetative and filamentous cells (a) and coccoid cyst-like structures or fruiting bodies (b, c) of strain T-22 ${ }^{\top}$ grown on MA for 5 (a), 10 (b) or 22 (c) days at $30^{\circ} \mathrm{C}$. Bars, $1 \mu \mathrm{m}$.

API ZYM strips (bioMérieux), respectively, according to the manufacturer's instructions. Physiological experiments using the API system, the determination of antibiotic resistance using ATB-VET and catalase and oxidase tests were repeated several times. Strain $\mathrm{T}-22^{\mathrm{T}}$ showed many characteristics that differentiated it from the closely related species C. alkaliphila (Table 1); additional features are included in the species description.

The major respiratory quinone system in strain $\mathrm{T}-22^{\mathrm{T}}$ was MK-7, as determined using the protocol described by Xie \& 
Table 1. Physiological characteristics of the members of the genus Chimaereicella

Data for C. alkaliphila AC-74 ${ }^{\mathrm{T}}$ were taken from Tiago et al. (2006) unless indicated. Both strains are positive for catalase, oxidase, aesculin hydrolysis, $\beta$-galactosidase, production of acid from D-galactose, D-glucose, D-cellobiose, D-maltose, D-lactose, potassium 5-ketogluconate, gentiobiose and D-turanose and resistance to kanamycin. Both strains are negative for urease, indole production from L-tryptophan, acid production from glycerol, erythritol, D- and L-arabinose, D-ribose, D- and L-xylose, D-adonitol, L-sorbose, dulcitol, inositol, D-mannitol, Dsorbitol, amygdalin, D-melezitose, xylitol, D-tagatose, D- and L-fucose, D- and L-arabitol, potassium gluconate, potassium 2-ketogluconate and methyl $\beta$-D-xylopyranoside and utilization of glycerol, erythritol, D-arabinose, D-ribose, D- and L-xylose, methyl $\beta$-D-xylopyranoside, Dgalactose, D-glucose, L-sorbose, L-rhamnose, inositol, $\mathrm{N}$-acetylglucosamine, D-lactose, D-melibiose, D-trehalose, D-raffinose, D-turanose, potassium gluconate, L-fucose and D-tagatose. Both species are sensitive to amoxicillin, colistin, doxycycline, ofloxacin, streptomycin and tetracycline. +, Positive; -, negative; (+), weakly positive.

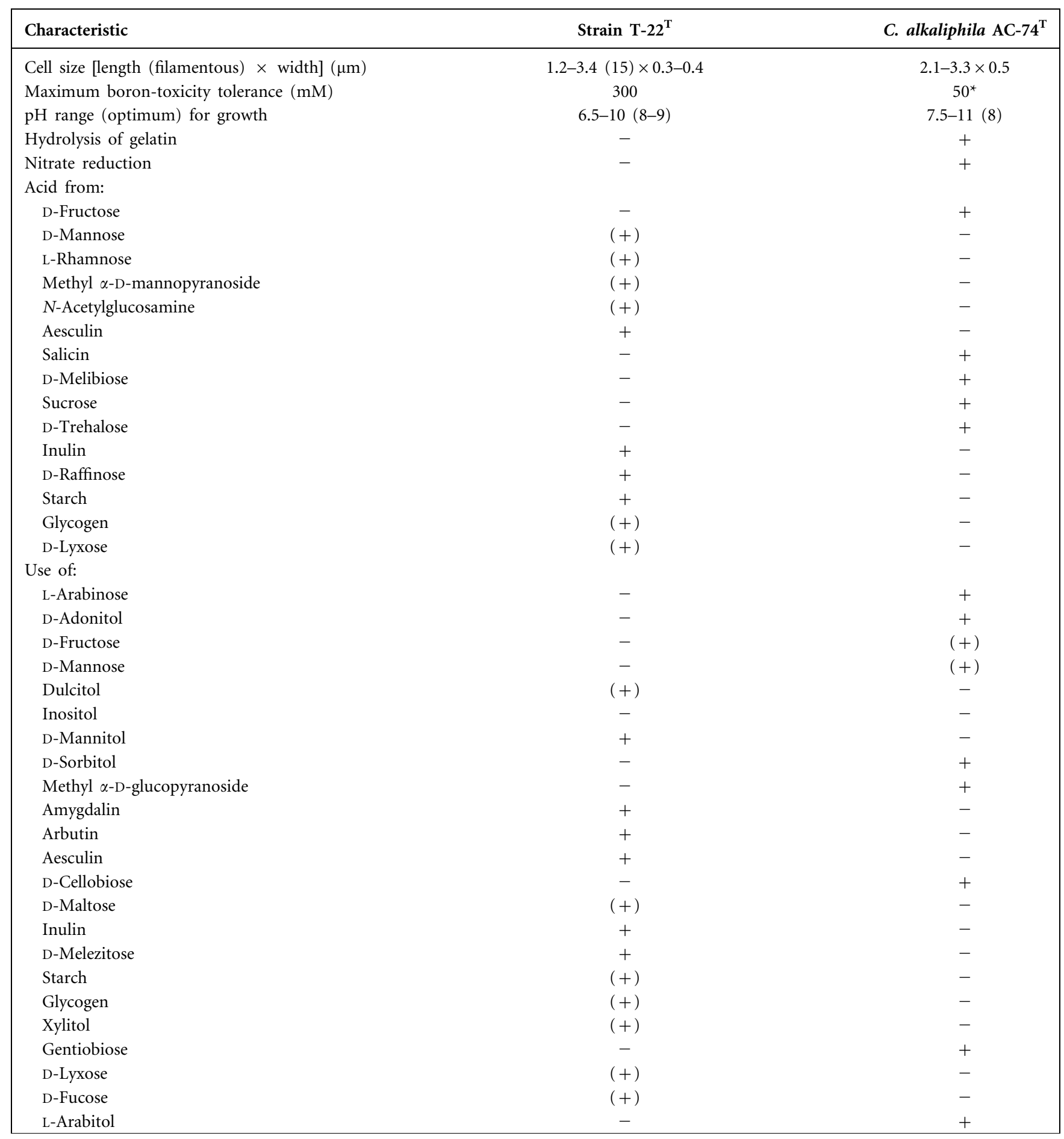


Table 1. cont.

\begin{tabular}{|lcc|}
\hline Characteristic & Strain T-22 & C. alkaliphila AC-74 $^{\text {T }}$ \\
\hline Potassium 2-ketogluconate & - & + \\
Potassium 5-ketogluconate & - & + \\
Resistance to: $\left(\mu \mathrm{g} \mathrm{ml}^{-1}\right)$ & & + \\
Cephalothin $(8)$ & - & + \\
Chloramphenicol $(30)$ & $(+)$ & - \\
Gentamicin $(4)$ & $(+)$ & - \\
Penicillin $(0.25)$ & 42.5 & 43.5 \\
DNA G+C content (mol\%) & \\
\hline
\end{tabular}

${ }^{\star}$ Data from this study.

Yokota (2003). To analyse the fatty acid profile, methyl ester derivatives were prepared by saponification, methylation and extraction from $10 \mathrm{mg}$ freeze-dried cell material harvested from either R3V-A or marine broth (MB; Difco). The fatty acid methyl esters were analysed using the GC-based Microbial Identification system (MIDI) following the manufacturer's instructions. The predominant cellular fatty acids detected in strain $\mathrm{T}-22^{\mathrm{T}}$ were branched-chain fatty acids, with the major entities iso- $\mathrm{C}_{15: 0}$, iso- $\mathrm{C}_{17: 1} \omega 9 c$, summed feature 3 (iso- $\mathrm{C}_{15: 0} 2-\mathrm{OH}$ and/or $\mathrm{C}_{16: 0} \omega 7 c$ ), iso- $\mathrm{C}_{17: 0} 3-\mathrm{OH}$ and iso- $\mathrm{C}_{16: 0}$ (Table 2).

Genomic DNA of the strain was isolated from cells grown on agar plates according to the method of Marmur (1961), with the slight modification of the use of RNase $\mathrm{T}_{1}$ in addition to RNase A. The DNA G $+\mathrm{C}$ content was determined as described previously (Ahmed et al., 2007a). The DNA G + C content of strain $\mathrm{T}-22^{\mathrm{T}}$ was $42.5 \mathrm{~mol} \%$.

An almost-complete 16S rRNA gene fragment (1489 nt) of strain $\mathrm{T}-22^{\mathrm{T}}$ was amplified by PCR and sequenced as described by Ahmed et al. (2007a) using an ABI PRISM 3730XL Genetic Analyzer (Applied Biosystems). The consensus sequence obtained using the DNASIS Pro software package (Hitachi Software Engineering) was compared with sequences of closely related type strains retrieved from the DDBJ/EMBL database using BLAST searches. The multiplesequence alignment was produced by CLUSTAL X $(1.8 \mathrm{msw})$ software (Thompson et al., 1997). Ambiguous positions and gaps were discarded and sequence identities were calculated using BioEdit software (Hall, 1999). Evolutionary distances and $K_{\text {nuc }}$ values (Kimura, 1980) were generated from unambiguous alignable data of $1342 \mathrm{nt}$ and phylogenetic trees were constructed using the neighbour-joining method (Saitou \& Nei, 1987) and maximum-parsimony and maximum-likelihood algorithms (Felsenstein, 2005). To assess the stability of relationships, a bootstrap analysis (confidence values estimated from 1000 replications of each sequence) was performed using PHYLIP software (Felsenstein, 2005) for the tree topology of the neighbourjoining data. Phylogenetic trees were plotted using the NJPlot software.
Comparison of the 16S rRNA gene sequence with those of closely related species showed that strain $\mathrm{T}-22^{\mathrm{T}}$ belonged to the genus Chimaereicella, with the highest similarity in the $16 \mathrm{~S}$ rRNA gene sequence of $97.4 \%$ with the sequence of C. alkaliphila $\mathrm{AC}-74^{\mathrm{T}}$. Sequence similarity calculations indicated that strain $\mathrm{T}-22^{\mathrm{T}}$ was equidistant from species of the genera Algoriphagus (similarity 94.0-95.4\%) and Hongiella (similarity 93.6-94.6\%) and occupied the phylogenetic position of C. alkaliphila AC- $74^{\mathrm{T}}$, achieving a $100 \%$ bootstrap value, indicating high reliability of the tree topology (Fig. 2). The topologies of the phylogenetic trees generated using the maximum-likelihood and maximum-parsimony algorithms were similar to that of the tree constructed using the neighbour-joining method (Supplementary Figs S1 and S2 available in IJSEM Online), especially for the clade comprising species of Chimaereicella. These analyses strongly support the affiliation of strain $\mathrm{T}-22^{\mathrm{T}}$ with the genus Chimaereicella.

For DNA-DNA hybridization experiments, Qiagen Genomic-tips 500/G were used to isolate genomic DNA of the novel strain and C. alkaliphila AC- $74^{\mathrm{T}}$ following the manufacturer's protocol, with the minor modification that RNase $T_{1}$ was used in addition to RNase A. DNA-DNA hybridization was performed at $42{ }^{\circ} \mathrm{C}$ with photobiotinlabelled DNA using microplates, as described by Ezaki et al. (1989). The DNA-DNA relatedness of strain T-22 ${ }^{\mathrm{T}}$ with C. alkaliphila $\mathrm{AC}-74^{\mathrm{T}}$ was $28.3 \%$, indicating that strain $\mathrm{T}-22^{\mathrm{T}}$ represents a distinct species (Stackebrandt \& Goebel, 1994).

Strain $\mathrm{T}-22^{\mathrm{T}}$ differed from the type species of the genus, $C$. alkaliphila, in that the latter cannot grow at neutral $\mathrm{pH}$ (Tiago et al., 2006). No growth of strain $\mathrm{T}-22^{\mathrm{T}}$ was observed at temperatures of 10 or $40^{\circ} \mathrm{C}$. This feature also differentiates the strain from C. alkaliphila and strains of the genera Algoriphagus and Hongiella, which can grow at or below $10^{\circ} \mathrm{C}$ (Bowman et al., 2003; Nedashkovskaya et al., 2004; Van Trappen et al., 2004; Yoon et al., 2004; Tiago et al., 2006). Strain $\mathrm{T}-22^{\mathrm{T}}$ survived on agar medium containing up to $300 \mathrm{mM}$ boron, whereas the closely related strain $C$. alkaliphila $\mathrm{AC}-74^{\mathrm{T}}$ could not tolerate $100 \mathrm{mM}$ boron. In 
Table 2. Cellular fatty acid compositions of strain $\mathrm{T}-22^{\top}$ and C. alkaliphila $\mathrm{AC}-74^{\top}$

Data for C. alkaliphila AC- $74^{\mathrm{T}}$ grown in R3V-A medium were taken from Tiago et al. (2006); the remaining data were obtained in this study. Values are percentages of total fatty acids; only fatty acids comprising $>0.50 \%$ in at least one of the strains are included.

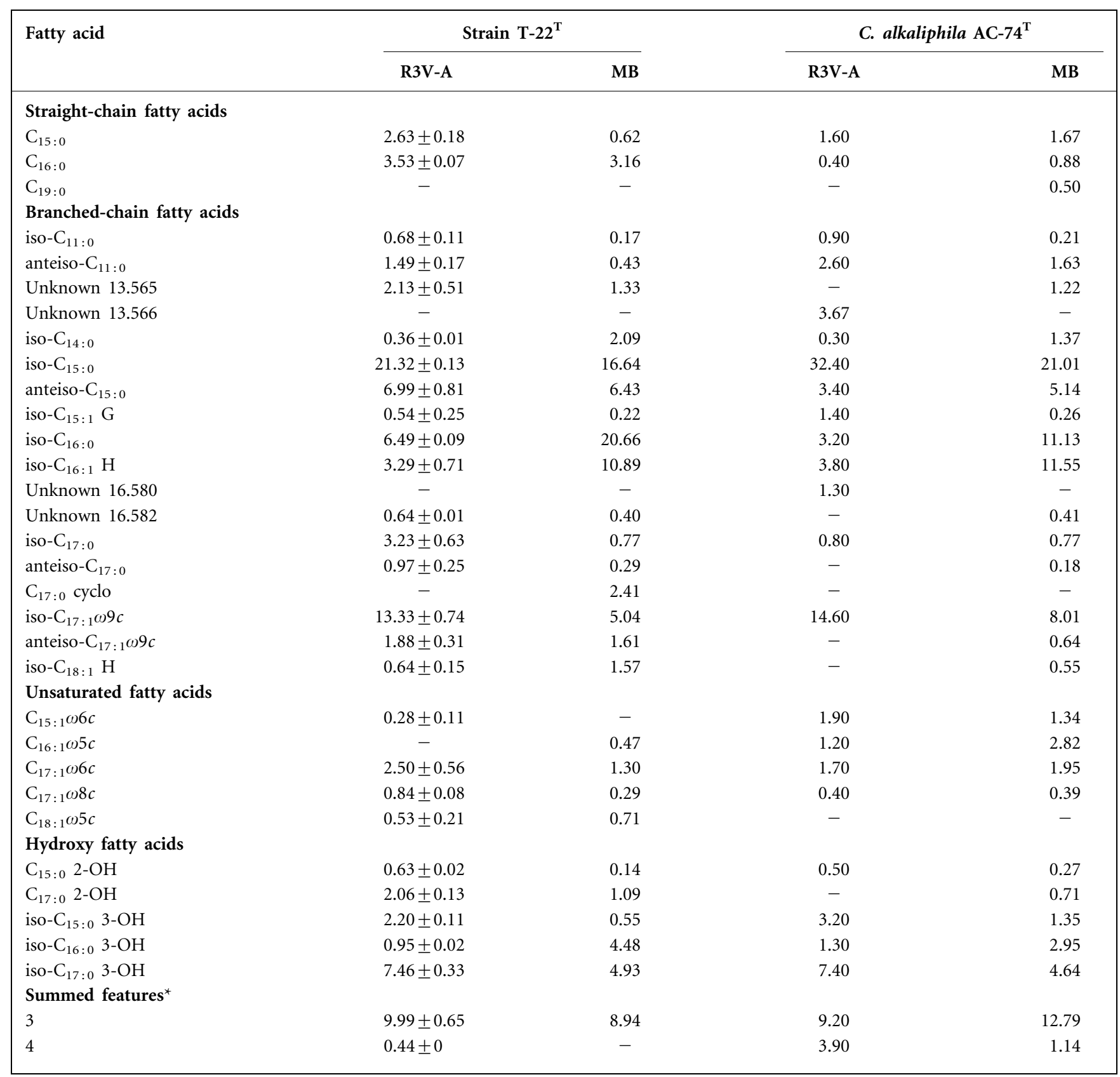

${ }^{*}$ Summed features 3 and 4 represent the fatty acids $\mathrm{C}_{16: 1} \omega 7 c$ and/or iso- $\mathrm{C}_{15: 0} 2-\mathrm{OH}$ and iso- $\mathrm{C}_{17: 1} \mathrm{I}$ and/or anteiso- $\mathrm{C}_{17: 1} \mathrm{~B}$, respectively, which cannot be separated reliably by the MIDI system.

addition to boron tolerance, the major differentiating characteristics of strain $\mathrm{T}-22^{\mathrm{T}}$ from the closely related type strain C. alkaliphila $\mathrm{AC}-74^{\mathrm{T}}$ were its negative results for gelatin hydrolysis and nitrate reduction tests and sensitivity to cephalothin and chloramphenicol.

The fatty acid profile of strain $\mathrm{T}-22^{\mathrm{T}}$ was similar to that of $C$. alkaliphila AC- $74^{\mathrm{T}}$ (Table 2). Strain $\mathrm{T}-22^{\mathrm{T}}$ produced a significant amount of the $\beta$-hydroxy fatty acids iso- $\mathrm{C}_{17: 0} 3$ $\mathrm{OH}$, iso- $\mathrm{C}_{16: 0} 3-\mathrm{OH}$ and iso- $\mathrm{C}_{15: 0} 3-\mathrm{OH}$ (Table 2), which are commonly found among members of the Flavobacteria (Bowman et al., 1998). The strain also contained an $\alpha$ hydroxy $(2-\mathrm{OH})$ fatty acid that is absent from the fatty acid profile of C. alkaliphila AC- $74^{\mathrm{T}}$. C. alkaliphila $\mathrm{AC}-74^{\mathrm{T}}$ has a DNA G + C content of $43.5 \mathrm{~mol} \%$, which was slightly higher than that of the novel strain. However, the highest 16S rRNA 


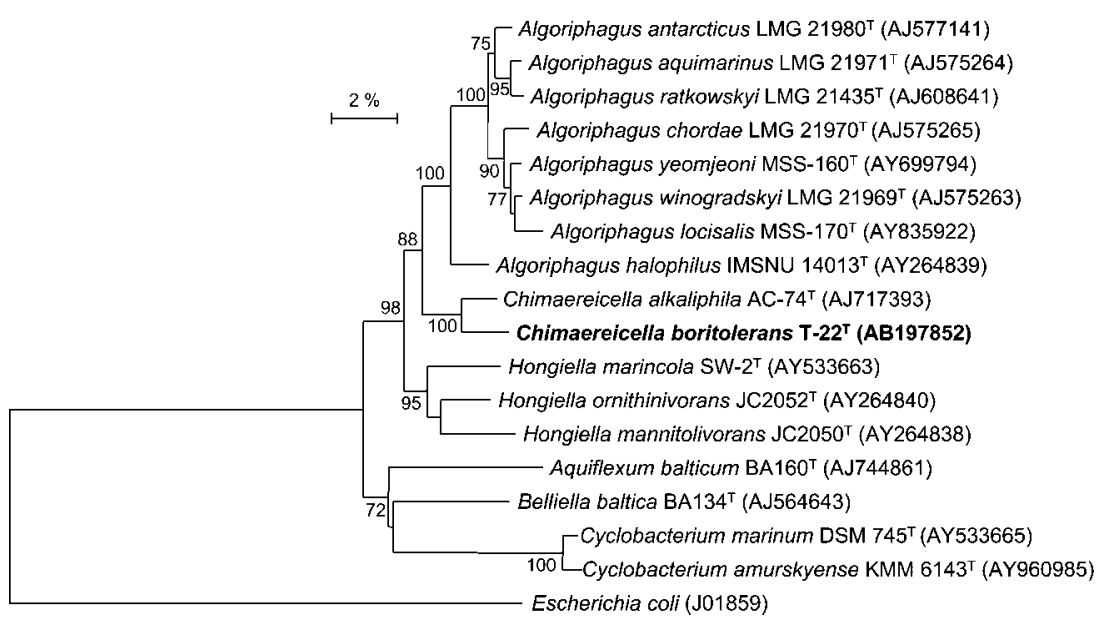

Fig. 2. Phylogenetic tree showing the interrelationships of strain $\mathrm{T}-22^{\top}$ and its closest relatives inferred from $16 \mathrm{~S}$ rRNA gene sequences. Data with gaps were removed during alignment using BioEdit software, and the tree was constructed using the neighbourjoining method with PHYLIP software (Felsenstein, 2005) based on a comparison of $1342 \mathrm{nt}$ and plotted with NJPlot. Bootstrap values $>70 \%$, expressed as percentages of 1000 replications, are given at branching points. The sequence of an unknown strain of Escherichia coli is used as the outgroup. Bar, $2 \%$ sequence divergence. gene sequence similarity occurred between strain $\mathrm{T}-22^{\mathrm{T}}$ and C. alkaliphila $\mathrm{AC}-74^{\mathrm{T}}$ (Fig. 1). Critical analysis of other physiological (Table 1) and chemotaxonomic (Table 2) data also suggests that strain $\mathrm{T}-22^{\mathrm{T}}$ belongs to the genus Chimaereicella.

Phylogenetic analysis based on the 16S rRNA gene sequence, the DNA base composition and chemotaxonomic analyses clearly suggest that strain $\mathrm{T}-22^{\mathrm{T}}$ belongs to the genus Chimaereicella. However, DNA-DNA relatedness and morphological and phenotypic characteristics $(\mathrm{pH}$ range for growth, boron tolerance, gelatin hydrolysis and nitrate reductase activity) suggest that it represents a novel species in the genus, for which we propose the name Chimaereicella boritolerans sp. nov.

\section{Description of Chimaereicella boritolerans sp. nov.}

Chimaereicella boritolerans (bo'ri.to'le.rans. N.L. n. borum boron; L. part. adj. tolerans tolerating; N.L. part. adj. boritolerans boron-tolerating).

Cells are non-motile and rod-shaped, 1.2-3.4 $\mu \mathrm{m}$ long and $0.3-0.4 \mu \mathrm{m}$ in diameter, occurring singly and occasionally in pairs. Gram staining is negative. Colonies are redpigmented, circular with entire margins, convex, butyrous in texture and small in diameter after several days of growth at $30^{\circ} \mathrm{C}$. The red pigment loses its intensity at $\mathrm{pH} 10.0$ on agar medium and is diffusible in liquid medium. Grows optimally at $28-30{ }^{\circ} \mathrm{C}$; very slight growth at 37 and $16^{\circ} \mathrm{C}$ after several days. The optimum $\mathrm{pH}$ for growth is $8.0-9.0$, with a range of $\mathrm{pH} 6.5-10.0$. Tolerates up to $300 \mathrm{mM}$ boron, but grows optimally without boron supply. $\mathrm{NaCl}$ is tolerated up to $3 \%(\mathrm{w} / \mathrm{v})$. Oxidase, catalase, hydrolysis of aesculin and $\beta$-galactosidase tests are positive, whereas tests for production of indole, nitrate reduction and hydrolysis of gelatin and urea are negative. Produces acid from the following substrates: D-galactose, D-glucose, aesculin, inulin, Draffinose, starch, D-cellobiose, D-maltose, D-lactose, potassium 5-ketogluconate, gentiobiose and D-turanose. Can use the following substrates as carbon sources: D-mannitol, amygdalin, arbutin, aesculin, inulin and D-melezitose. Additional physiological characteristics are provided in Table 1. Major cellular fatty acids are iso- $\mathrm{C}_{15: 0}$, iso$\mathrm{C}_{17: 1} \omega 9 c$, summed feature 3 (iso- $\mathrm{C}_{15: 0} \quad 2-\mathrm{OH}$ and/or $\mathrm{C}_{16: 1}(\omega 7 c)$, iso- $\mathrm{C}_{17: 0} 3-\mathrm{OH}$ and iso- $\mathrm{C}_{16: 0}$; traces of some other fatty acids are apparent. The respiratory lipoquinone system is MK-7. Strong enzyme activity is observed for alkaline phosphatase, $\alpha$-chymotrypsin, $N$-acetyl- $\beta$-glucosaminidase and valine arylamidase, whereas weak activity is observed for leucine arylamidase, naphthol-AS-BI-phosphohydrolase, esterase (C8), esterase lipase (C8), trypsin, acid phosphatase, $\beta$-galactosidase and $\alpha$-glucosidase (API ZYM strip). Resistant to kanamycin, oxacillin, sulfamethizol and metronidazol and weakly sensitive to penicillin, gentamicin, rifampicin and cefoperazon (ATB-VET strip). The $\mathrm{G}+\mathrm{C}$ content of the type strain is $42.5 \mathrm{~mol} \%$.

The type strain is strain $\mathrm{T}-22^{\mathrm{T}}\left(=\mathrm{DSM} 17298^{\mathrm{T}}=\mathrm{NBRC}\right.$ $101277^{\mathrm{T}}=$ ATCC BAA- $1189^{\mathrm{T}}$ ), isolated from soil that naturally contains boron (Hisarcik, Kutahya, Turkey).

\section{Acknowledgements}

We are thankful to Dr Cavit Çöl for collecting soil samples from the Hisarcik area of Turkey, Dr I. Tiago for providing strain AC-74 ${ }^{\mathrm{T}}$ and JEOL (Japan) for their help with the electron microscopy.

\section{References}

Ahmed, I., Yokota, A. \& Fujiwara, T. (2007a). A novel highly boron tolerant bacterium, Bacillus boroniphilus sp. nov., isolated from soil, that requires boron for its growth. Extremophiles 11, 217-224.

Ahmed, I., Yokota, A. \& Fujiwara, T. (2007b). Gracilibacillus boraciitolerans sp. nov., a highly boron-tolerant and moderately halotolerant bacterium isolated from soil. Int J Syst Evol Microbiol 57, 796-802.

Bowman, J. P. \& Nichols, D. S. (2005). Novel members of the family Flavobacteriaceae from Antarctic maritime habitats, including Subsaximicrobium wynnwilliamsii gen. nov., sp. nov., Subsaximicrobium saxinquilinus sp. nov., Subsaxibacter broadyi gen. nov., sp. nov., Lacinutrix copepodicola gen. nov., sp. nov., and novel species 
of the genera Bizionia, Gelidibacter and Gillisia. Int J Syst Evol Microbiol 55, 1471-1486.

Bowman, J. P., McCammon, S. A., Lewis, T., Skerratt, J. H., Brown, J. L., Nichols, D. S. \& McMeekin, T. A. (1998). Psychroflexus torquis gen. nov., sp. nov., a psychrophilic species from Antarctic sea ice, and reclassification of Flavobacterium gondwanense (Dobson et al. 1993) as Psychroflexus gondwanense gen. nov., comb. nov. Microbiology 144, 1601-1609.

Bowman, J. P., Nichols, C. M. \& Gibson, J. A. E. (2003). Algoriphagus ratkowskyi gen. nov., sp. nov., Brumimicrobium glaciale gen. nov., sp. nov., Cryomorpha ignava gen. nov., sp. nov. and Crocinitomix catalasitica gen. nov., sp. nov., novel flavobacteria isolated from various polar habitats. Int J Syst Evol Microbiol 53, 1343-1355.

Çöl, M. \& Çöl, C. (2003). Environmental boron contamination in waters of the Hisarcik area in the Kutahya Province of Turkey. Food Chem Toxicol 41, 1417-1420.

Cowan, S. T. \& Steel, K. J. (1974). Cowan and Steel's Manual for the Identification of Medical Bacteria, 2nd edn. London: Cambridge University Press.

Ezaki, T., Hashimoto, Y. \& Yabuuchi, E. (1989). Fluorometric deoxyribonucleic acid-deoxyribonucleic acid hybridization in microdilution wells as an alternative to membrane filter hybridization in which radioisotopes are used to determine genetic relatedness among bacterial strains. Int J Syst Bacteriol 39, 224-229.

Felsenstein, J. (2005). PHYLIP (Phylogeny Inference Package) version 3.6. Distributed by the author. Department of Genome Sciences, University of Washington, Seattle, USA.

Hall, T. A. (1999). BioEdit: a user-friendly biological sequence alignment editor and analysis program for Windows 95/98/NT. Nucleic Acids Symp Ser 41, 95-98.

Jones, B. E., Grant, W. D., Collins, N. C. \& Mwatha, W. E. (1994). Alkaliphiles: diversity and identification. In Bacterial Diversity and Systematics, pp. 195-230. Edited by F. G. Priest, A. RamosCormenzana \& B. J. Tindall. New York: Plenum.

Kimura, M. (1980). A simple method for estimating evolutionary rates of base substitutions through comparative studies of nucleotide sequences. J Mol Evol 16, 111-120.

Kirchman, D. L. (2002). The ecology of Cytophaga-Flavobacteria in aquatic environments. FEMS Microbiol Ecol 39, 91-100.

Marmur, J. (1961). A procedure for the isolation of deoxyribonucleic acid from microorganisms. J Mol Biol 3, 208-218.
Nable, R. O., Bañuelos, G. S. \& Paull, J. G. (1997). Boron toxicity. Plant Soil 193, 181-198.

Nedashkovskaya, O. I., Vancanneyt, M., Van Trappen, S., Vandemeulebroecke, K., Lysenko, A. M., Rohde, M., Falsen, E., Frolova, G. M., Mikhailov, V. V. \& Swings, J. (2004). Description of Algoriphagus aquimarinus sp. nov., Algoriphagus chordae sp. nov. and Algoriphagus winogradskyi sp. nov., from sea water and algae, transfer of Hongiella halophila Yi and Chun 2004 to the genus Algoriphagus as Algoriphagus halophilus comb. nov. and emended descriptions of the genera Algoriphagus Bowman et al. 2003 and Hongiella Yi and Chun 2004. Int J Syst Evol Microbiol 54, 1757-1764.

Rowe, R. I. \& Eckhert, C. D. (1999). Boron is required for zebra fish embryogenesis. J Exp Biol 202, 1649-1654.

Saitou, N. \& Nei, M. (1987). The neighbor-joining method: a new method for reconstructing phylogenetic trees. Mol Biol Evol 4, 406-425.

Stackebrandt, E. \& Goebel, B. M. (1994). Taxonomic note: a place for DNA-DNA reassociation and $16 \mathrm{~S}$ rRNA sequence analysis in the present species definition in bacteriology. Int J Syst Bacteriol 44, 846-849.

Stanier, R. Y., Palleroni, N. J. \& Doudoroff, M. (1966). The aerobic pseudomonads: a taxonomic study. J Gen Microbiol 43, 159-271.

Thompson, J. D., Gibson, T. J., Plewniak, F., Jeanmougin, F. \& Higgins, D. G. (1997). The CLUSTAL_X windows interface: flexible strategies for multiple sequence alignment aided by quality analysis tools. Nucleic Acids Res 25, 4876-4882.

Tiago, I., Mendes, V., Pires, C., Morais, P. V. \& Veríssimo, A. (2006). Chimaereicella alkaliphila gen. nov., sp. nov., a Gram-negative alkaliphilic bacterium isolated from a nonsaline alkaline groundwater. Syst Appl Microbiol 29, 100-108.

Van Trappen, S., Vandecandelaere, I., Mergaert, J. \& Swings, J. (2004). Algoriphagus antarcticus sp. nov., a novel psychrophile from microbial mats in Antarctic lakes. Int J Syst Evol Microbiol 54, 1969-1973.

Warington, K. (1923). The effect of boric acid and borax on the broad bean and certain other plants. Ann Bot 37, 629-672.

Xie, C. \& Yokota, A. (2003). Phylogenetic analysis of Lampropedia hyalina based on the 16S rRNA gene sequence. J Gen Appl Microbiol 49, 345-349.

Yoon, J.-H., Yeo, S.-H. \& Oh, T.-K. (2004). Hongiella marincola sp. nov., isolated from sea water of the East Sea in Korea. Int J Syst Evol Microbiol 54, 1845-1848. 